\title{
Acoustic performance in a lightweight ventilated façade for building refurbishment: analysing the impact of variations in airborne sound insulation according to the ventilation characteristics
}

\author{
Comportamiento acústico de una fachada ventilada ligera en el caso de la rehabilitación de \\ edificios: análisis del impacto de las variaciones en el aislamiento acústico aéreo, obtenido \\ según las características de la ventilación
}

Andrea Niampira Daza (Main and Corresponding Author)

Universidad Piloto de Colombia

Facultad de Arquitectura

Cra. 9 No. 45A-44, 110311 Bogota, Colombia

york-niampira@upc.edu.co

\section{Joan Lluís Zamora}

Universitat Politècnica de Catalunya

Departament de Tecnologia de l'Arquitectura

Av. Diagonal, 649, 08028 Barcelona, Spain

joan.lluis.zamora@upc.edu

Manuscript Code: 1178

Date of Acceptance/Reception: 11.07.2019/05.09.2018

DOI: 10.7764/RDLC.18.2.247

\begin{abstract}
The use of double-sheet enclosures with an intermediate air chamber in façades guarantees a higher quality of acoustic insulation against external airborne noise. The effective advantages of the intermediate air chamber depend mainly on its airtightness and the absorbent material contained inside. A ventilated façade with lightweight cladding (LVF) is a specific construction system for double-sheet envelope façades, characterised by an intermediate air chamber that enables a certain amount of internal air circulation, with resulting cooling effects to alleviate excess solar radiation whilst reducing the risk of dampness caused by rainwater. However, owing to this ventilation of the intermediate air chamber, the acoustic insulation of the entire façade could prove less effective than cases in which the intermediate air chamber is completely sealed. Through various methods of measurement and analysis, several authors consider that the opening of the intermediate air chamber for hygrothermal control purposes does not necessarily represent a significant reduction in the level of sound insulation in general. What does appear to have a significant influence on the acoustic behaviour is the surface and location of the intermediate air chamber openings to enable ventilation. The results of this research are presented as further evidence that the positive contribution of LVF should be acknowledged at a regulatory level regarding sound insulating, double-sheet envelope architectural façades.
\end{abstract}

Keywords: Ventilated air cavity, airborne sound insulation, lightweight ventilated façade (LVF), building refurbishment.

\begin{abstract}
Resumen
El uso de cerramientos de doble hoja en fachadas con una cámara de aire intermedia garantiza una mayor calidad de aislamiento acústico contra el ruido aéreo. Las ventajas efectivas de la cámara de aire intermedia dependen principalmente de su hermeticidad y del material absorbente acústico que contiene. La fachada ventilada con revestimiento ligero (LVF) es un sistema de construcción específico para fachadas de doble hoja, caracterizada por la cámara de aire intermedia que permite una cierta circulación de aire interna, con los efectos beneficiosos de enfriamiento resultantes para aliviar el exceso de radiación solar y reducir el riesgo de humedad causado por el agua de lluvia. Sin embargo, debido a esta ventilación de la cámara de aire intermedia, el aislamiento acústico de toda la fachada podría resultar menos efectivo que cuando se compara con los casos en que la cámara de aire intermedia está completamente sellada. Sin embargo, a través de diferentes métodos de medición y análisis, varios autores consideran que la apertura de la cámara de aire intermedia para fines de control higrotérmico no representa necesariamente una reducción significativa del nivel de aislamiento acústico en su conjunto. Lo que sí parece tener una influencia significativa en el comportamiento acústico del conjunto, es la superficie y la ubicación de las aberturas de la cámara de aire intermedia necesarias para permitir la ventilación. Los resultados de esta investigación se presentan como evidencia adicional de que la contribución acústica positiva de las LVF debe reconocerse a nivel normativo.
\end{abstract}

Palabras clave: Cámara de aire ventilada; aislamiento acústico al ruido aéreo; fachada ventilada ligera (LVF), rehabilitación de edificios

Introduction

Lightweight Ventilated Façades (LFV) is a construction system for façades consisting of a double envelope with a heavy inner sheet and a lightweight outer sheet, which delimits an intermediate air chamber between the two sheets. This usually has openings for ventilation and hygrothermal purposes. The LVF is a construction subtype of the Ventilated 
Façade, according to most authors (Paricio \& Pardal, 2006; Mosqueira, 2003) and manufacturers (Knauf GmbH Company, 2009). This system is commonly used in new constructions and to refurbish building façades. With the use of a ventilated intermediate air chamber, the double envelope has better thermal conditions and watertightness than a single envelope (Braganca, Wetzel, Buhagiar, \& Verhoef, 2007; Pérez, Álvarez, \& Montero, 2007; Adjemia, 2011). The ventilation openings of this intermediate air chamber are available either by using coupling joints for the boards that form the outer sheet (in accordance with the board formats used) or on the upper and lower limits of the intermediate air chamber. Openings are usually distributed equally to guarantee adequate, uniform, constant ventilation (Niampira Daza, 2014).

\section{Description of the problem}

The insulating behaviour of a single façade wall against outside noise analytically resembles the law of mass action. According to this physical law, when the surface density is doubled of a wall with a certain surface density $\sigma\left(\mathrm{Kg} / \mathrm{m}^{2}\right)$ and a certain level of acoustic insulation, its Transmission Loss (TL) value is not doubled. The increase in acoustic insulation that is achieved does not exceed $15 \%$ of the starting point (Harris, 1995; Hopkins, 2007). Therefore, at a practical and economic level, it is not feasible to increase the envelope wall thickness to reduce its surface density $\sigma$ and hence reduce its value (TL). The acoustic insulation level of a single wall cannot be more efficiently improved with additional unlinked layers of material of a different thickness and mechanical rigidity, according to the model of the law of mass-spring-mass (Harris, 1995; Hopkins, 2007). One of the most commonly used layers is the unventilated intermediary air chamber, due as much to its low cost as its light weight. The progressive increase in thickness of this intermediate air chamber could also represent a qualitative and quantitative increase in performance (Hopkins, 2007; Ministerio de Fomento, Gobierno de España, 2008; Warnock \& Quirt, 1997) in terms of the level of demonstrated acoustic insulation.

Most construction codes establish the minimum regulatory requirements of ventilated intermediate air chambers. The Spanish Technical Building Code indicates that intermediate air chambers used in double façade envelopes should meet the specifications of "chamber thickness from $3 \mathrm{~cm}$ to $10 \mathrm{~cm}$ and the minimum effective ventilation area of 120 $\mathrm{cm}^{2}$ per every $10 \mathrm{~m}^{2}$ of façade panel between slabs. Area divided at $50 \%$ between the upper and lower part" (Ministerio de Fomento, Gobierno de España, 2008).

Based on research and trials performed by various authors and acoustic measurements made in different fields, there are evident indicators that a double sheet with an intermediate air cavity raises airborne sound insulation depending on the thickness of the air cavity and the absorber material that is included (Halliwell, Nightingale, Warnock, \& Birta, 1998; Hongisto, 2000; Frutos, Olaya, \& Zaballos, 2008; Dijckmans, Vermeir, \& Lauriks, 2010). The resonator system can contribuite at low frequencies (Fahy, 1985) and the type of profile and distance between elements in a substructure can influence the results of sound reduction in an intermediate air cavity (Warnock \& Quirt, 1997).

Regarding the façade, the performance of sound insulation in a double wall with an intermediate air cavity is not fully affected by the moderate ventilation of the air cavity advocated by European construction codes for hygrothermal control purposes. A simple sheet traditional façade in an office building shows a $6 \mathrm{~dB}$ sound reduction index, which is less than a double glass façade with a ventilated air cavity (Blasco, Crispin, \& Ingelaere, 2004). In a trial, six envelope prototypes were subjected to acoustic testing. Three of the prototypes were traditional multilayer facades: one without an intermediate air cavity, one with a ventilated intermediate air cavity and one with a non-ventilated air cavity. The other three prototypes were multilayer lightweight façades: two with intermediate ventilated air cavity systems and one without an intermediate air cavity. The results indicated that the prototypes without an intermediate ventilated air cavity had better sound reduction but the systems with intermediate air cavities had good acoustic behaviour, above the requirements of Spanish acoustic regulation code CTE DB-HR (Ruiz, Delgado, Neila, \& Vega, 2012).

To check this assumption and define its scope quantitatively, this study assesses the influence of various ventilation variables on the value of the airborne acoustic insulation level of a double-sheet façade envelope. The following are considered: $a$. the thickness of the intermediate air chamber; $b$. the use of acoustically absorbent material inside the chamber; c. the opening surface for ventilation; $d$. the layout of ventilation openings in the intermediate air chamber. 
The ventilated façade with lightweight cladding (LVF) has high added potential for acoustic use compared to a single envelope. The continuity of the intermediate air chamber decreases flanking transmission and even reduces some vibro-acoustic transmission that may occur inside the chamber, as long as acoustic absorbent material is used (Hopkins C., 2007). Its contribution to improving the level of acoustic insulation in each case appears to depend, in principle, on the thickness of the intermediate air chamber, its absorbent acoustic characteristics and the layout and size of ventilation openings.

The general objective of this research is to assess the level of acoustic insulation of the LVF with the interpositioning of the intermediate ventilated air chamber, using several campaigns with different locations and conditions. To achieve this, an on-site test is proposed that was undertaken on a façade of the Vallès School of Architecture (ETSAV) of the Universitat Politècnica de Catalunya (UPC) (Sant Cugat del Vallès, Barcelona, Spain). In this test, a traditional façade on a single, heavy sheet was converted into an LVF by adding a substructure frame, an insulating material and external cladding made from CB (Cement Board: cement mortar reinforced with glass fibres).

\section{On-site measurement}

On-site measurements provide empirical knowledge of the actual acoustic behaviour of LVF. They also provide information required for subsequent simulation tests using computer modelling. The LVF construction system used was the commercial standard system called Aquapanel ${ }^{\circ}$ (Knauf $\mathrm{GmbH}$ ) from (Figure 1). This system was chosen for its accessibility and versatility. The system's lightweight outer sheet is composed of $1.20 \times 2.40 \mathrm{~m}$ panel of CB with a thickness of $12.5 \mathrm{~mm}$. Joints between boards can be open or sealed. The thickness of the intermediate air chamber is constant and is determined by the width of the metal brackets that are anchored to the inside sheet. These brackets hold the cantilevered metal framing of the substructure that holds the boards of the lightweight outer sheet. The inside of the intermediate air chamber also includes a layer of acoustically absorbent material, which is a rock wool blanket (Figure 1).

Figure 1. Isometrics of the Aquapanel LVF system, description of the substructure and
fastening elements. Source: Knauf GmbH (2010): Façade cladding, specification Sheet W68E (adapted by authors).

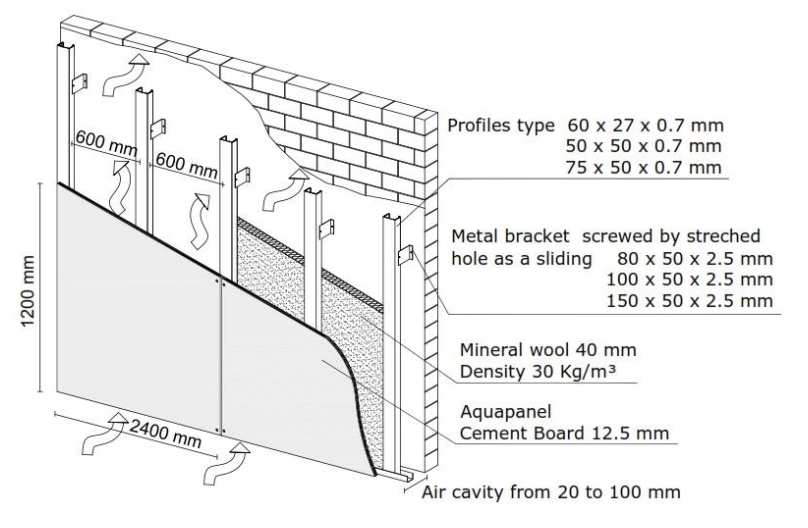

\section{Mathematical model of reference}

To carry out the on-site acoustic test, the airborne sound insulation was determined by the mathematical expressions established in current regulations for acoustic measurements used to obtain and calculate acoustic insulation level results (UNE-EN 12354-3, 2001) and (UNE-EN 140-5, 1999). The sound reduction index $R$ and the standardised level difference $D_{2 m, n T}$, which is the difference between the outdoor sound pressure level from 2 metres in front of the façade and the sound pressure level inside of the receiving room, were evaluated. This method is normally used in onsite sound measures testing. To review the results, the standard (UNE EN ISO 717-1, 1997) Evaluation of acoustic insulation in buildings and in their construction elements. Part 1: Airborne noise insulation. August 1997 was applied.

During the testing evaluation of the acoustic behaviour in the double-sheet façade, certain sound frequencies were observed in the environment, from which a sharp fall in the level of acoustic insulation is produced. Frequencies that show a sharp reduction are associated with the coincidence or critical frequency by the formula: 


$$
F c=\left(c^{2} / 1,8 d\right) \sqrt{\frac{\rho}{E}}
$$

Where:

$\mathrm{c}=$ sound velocity $(345 \mathrm{~m} / \mathrm{s})$

$d=$ thickness of the sheet in metres $(\mathrm{m})$

$\rho=$ density in in $\mathrm{kg} / \mathrm{m} 3$

$\mathrm{E}=$ Young modulus

Table 1. Results of the estimate by calculating the coincidence frequency (fc). (Source: compiled by the authors).

\begin{tabular}{lcc}
\hline \multicolumn{3}{c}{ Individual coincidence frequency $\left(f_{c}\right)$ of several wall sheets } \\
\hline Lower sheet: double brick & Coincidence frequency $\left(f_{c}\right)$ & $139 \mathrm{~Hz}$ \\
masonry wall $(300 \mathrm{~mm})$ with an & outside uncladded brick wall $(140 \mathrm{~mm})$ & \\
unventilated intermediate air & Coincidence frequency $\left(f_{c}\right)$ & $269 \mathrm{~Hz}$ \\
chamber of $(70 \mathrm{~mm})$ & lower unclad ceramic brick wall $(90 \mathrm{~mm})$ & \\
Outer sheet of CB boards & Coincidence frequency $\left(f_{c}\right)$ & $2470 \mathrm{~Hz}$ \\
$12.5 \mathrm{~mm}$ & CB cement boards $(12.5 \mathrm{~mm})$ & \\
\hline
\end{tabular}

The natural (or resonance) frequency of the set of walls, refers to a system formed by two masses $m 1$ and $m 2$ (inside sheet and outside sheet) joined by a spring (intermediate air chamber) of rigidity $K$. This mass-spring-mass system, with joint vibrating capacity, has its own resonance frequency $\left(f_{\mathrm{msm}}\right)$ at $20^{\circ} \mathrm{C}$, which is determined through the following formula:

$$
f_{\mathrm{msm}}=60 \sqrt{\frac{\rho s_{1}+\rho s_{2}}{\rho s_{1} \rho s_{2} L_{\mathrm{z}}}}
$$

Equation 2 (Hopkins, 2007)

Where:

$\rho s=$ mass per area unit (surface density in $\mathrm{kg} / \mathrm{m} 2$ ) of each sheet

$\mathrm{d}=$ thickness of the sheet in metres $(\mathrm{m})$

$K=60$, for an empty air chamber (without acoustically absorbent material)

$\mathrm{Lz}=$ thickness of the chamber in metres $(\mathrm{m})$

If the intermediate air chamber is fully or partially filled with acoustically absorbent material, the proper frequency can be determined by the following formula:

$$
f_{\mathrm{msm}}=\frac{1}{2 \pi} \sqrt{\frac{S^{\prime} \mathrm{g}}{\frac{\rho S_{1} \rho S_{2}}{\rho S_{1}+\rho S_{2}}}}
$$

Equation 2 (Hopkins, 2007)

In this case, $\left(\mathrm{S}_{\mathrm{g}}^{\prime}\right)$ is the value corresponding to $K$ when the chamber has acoustically absorbent material inside. In a fully or partially filled chamber, this value divides the elasticity module $E$ of the acoustically absorbent material by its thickness. In a chamber partially filled with acoustically absorbent material, it is possible to determine the natural frequency of the absorbent material through Equation 1 and by adopting the effective thickness of the chamber through the following formula:

$$
\mathrm{Lz}, \mathrm{eff}=(\mathrm{Lz}-\mathrm{d})+\phi \mathrm{d}
$$

Equation 3 (Hopkins, 2007)

Where:

$L_{z, \text { eff }}=$ is the effective depth of the chamber in metres $(\mathrm{m})$

$L z=$ depth of the chamber in metres $(\mathrm{m})$ 
$\mathrm{d}=$ thickness of the porous material in metres $(\mathrm{m})$

$\phi=$ porosity coefficient of the absorbent material (value between 0 and 1 )

Table 2 summarizes the resonance frequency of double systems $f_{m s m}$ obtained for each of the models that were evaluated.

\begin{tabular}{l} 
Table 2. Result of calculating the frequency of the double system $\left(f_{m s m}\right)$ of tests 1 and 2 (Source: compiled by authors). \\
$\begin{array}{ll}\text { Resonance frequency }\left(f_{m s m}\right) \text { of the double envelopes } \\
\text { On-site test }\end{array}$ \\
$\begin{array}{l}\text { Resonance frequency } f_{m s m} \text { of the lower } \\
\text { sheet, formed by the double masonry, } \\
\text { fired clay brick wall }(300 \mathrm{~mm})\end{array}$ \\
\hline
\end{tabular}

This test was carried out in February 2011 on the façade of the building of the Vallès School of Architecture (ETSAV), Universitat Politècnica de Catalunya (UPC) in Sant Cugat del Vallès, (Barcelona, Catalonia) Spain (41.470111 N, $2.071592 \mathrm{E}$ ). A section of façade was selected for the trial that was $9.60 \mathrm{~m}$ in width by $6.02 \mathrm{~m}$ in height (see Fig. 2), formed by a double masonry brick wall with a thickness of $30 \mathrm{~cm}$ (Figure 3) and $217 \mathrm{Kg} / \mathrm{m}^{2}$ surface density, with an acoustic insulation value of approximately $44 \mathrm{dBA}$ RW $\mathrm{w}_{\mathrm{ATr}}$. according to former Spanish acoustic regulation NBE CA-88 annex 3.2.4. Facades, and $47 \mathrm{~dB} \mathrm{D}_{\mathrm{nT}} \mathrm{w}$, according to testing of on-site data without the lightweight system.

\section{Description of the specimen test}

For this trial case, the existing wall was used as a base inner sheet to install the LVF assembly. The lightweight outer sheet was made from CB boards, according to the Aquapanel ${ }^{\circ}$ (Knauf $\mathrm{GmbH}$ ) commercial procedure, to create an LVFtype façade. The acoustic measurements were made by applying standard (UNE-EN ISO 140-5, 1998) Measurement of acoustic insulation in buildings and construction elements. Part 5: On-site measurements of the airborne acoustic insulation of façade elements.

The lightweight outer sheet was built in three configurations:

- Continuous sheet with joints sealed between boards (Fa)

- Continuous sheet with open joints $(5 \mathrm{~mm})$ between boards (Fb)

- Continuous sheet of $350 \mathrm{~mm}$-wide slats slightly slanted 15 (Fd) (Figure 4)

The thickness of the air chamber $(100 \mathrm{~mm})$ was the same for all three configurations of the outer sheet. CB boards were attached to a substructure of omega section metal profiles measuring $50 \times 50 \mathrm{~mm}$, placed vertically every 600 $\mathrm{mm}$ in the façade panel. A 40-mm thick rock wool blanket, with a density of $30 \mathrm{Kg} / \mathrm{m}^{3}$, was placed in the intermediate air chamber.

Figure 2. Proposed configurations for the outer sheet of the LVF. (Source: compiled by authors).
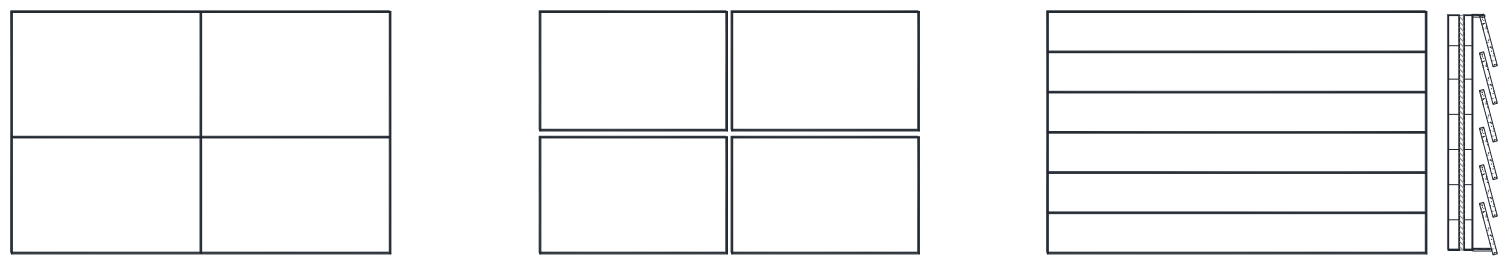
Figure 3. Elevation detail of the façade section in the on-site test ETSAV building. (Source: compiled by authors).

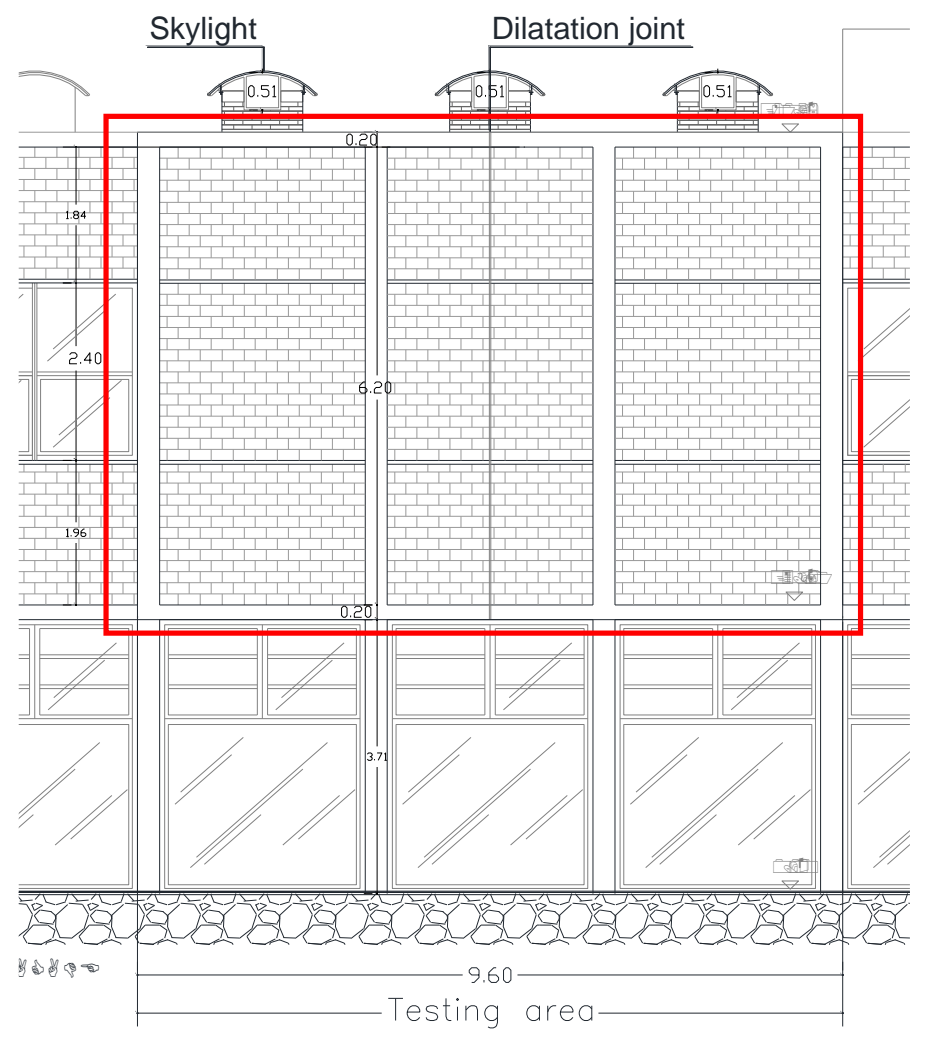

The thickness of the air chamber $(100 \mathrm{~mm})$ was the same in all three configurations of the outer sheet. CB boards were attached to a substructure of omega section metal profiles measuring $50 \times 50 \mathrm{~mm}$, placed vertically every 600 $\mathrm{mm}$ in the façade panel (Figures 5 and 6). A $40 \mathrm{~mm}$-thick rock wool blanket, with a density of $30 \mathrm{Kg} / \mathrm{m}^{3}$ was placed in the intermediate air chamber.

The intermediate air chamber ventilation of LVF was secured, with ventilation openings of the intermediate air chamber on the upper and lower edge. To evaluate the acoustic behaviour of the assembly to different ventilation intensities, a manual modification system was implemented of the surface extension of the upper and lower ventilation openings (Figure 6) until 5 levels were separated.

\section{Acoustically significant characteristics of specimen test}

The following table (Table 3) indicates the thickness, surface density and density values of each layer of the LVF assembly, to evaluate the acoustic behaviour.

Table 3. Main physical-construction characteristics of the LVF assembly of on-site test. (Source: compiled by authors).

\begin{tabular}{|c|c|c|c|c|c|c|c|c|c|c|}
\hline \multicolumn{11}{|c|}{ LVF prototype constructed on site test } \\
\hline \multicolumn{5}{|c|}{$\begin{array}{l}\text { Inner sheet } \\
\text { Double fired clay hollow brick masonry wall }\end{array}$} & \multicolumn{3}{|c|}{$\begin{array}{l}\text { Intermediate chambers filled partially } \\
\text { with mineral wool }\end{array}$} & \multicolumn{3}{|c|}{$\begin{array}{l}\text { Outer sheet } \\
\text { Cement Board (CB) }\end{array}$} \\
\hline $\begin{array}{l}\text { Wall } 1 \\
(\mathrm{~mm}) \\
\end{array}$ & $\begin{array}{c}\text { Air } \\
\text { chamber } \\
(\mathrm{mm})\end{array}$ & $\begin{array}{l}\text { Wall } 2 \\
(\mathrm{~mm}) \\
\end{array}$ & $\begin{array}{l}\text { Surface } \\
\text { density } \\
\left(\mathrm{Kg} / \mathrm{m}^{2}\right)\end{array}$ & $\begin{array}{l}\text { Density } \\
\left(\mathrm{Kg} / \mathrm{m}^{3}\right)\end{array}$ & $\begin{array}{c}\text { Total } \\
\text { thickness } \\
(\mathrm{mm}) \\
\end{array}$ & $\begin{array}{c}\text { Mineral wool } \\
\text { thickness } \\
(\mathrm{mm}) \\
\end{array}$ & $\begin{array}{c}\text { Density } \\
\text { Mineral wool } \\
\left(\mathrm{Kg} / \mathrm{m}^{3}\right)\end{array}$ & $\begin{array}{c}\text { Thickness } \\
(\mathrm{mm}) \\
\end{array}$ & $\begin{array}{l}\text { Surface } \\
\text { density } \\
\left(\mathrm{Kg} / \mathrm{m}^{2}\right)\end{array}$ & $\begin{array}{l}\text { Density } \\
\left(\mathrm{Kg} / \mathrm{m}^{3}\right)\end{array}$ \\
\hline 140 & 70 & 90 & \multirow{2}{*}{217} & \multirow{2}{*}{943} & \multirow{2}{*}{100} & \multirow{2}{*}{40} & \multirow{2}{*}{30} & \multirow{2}{*}{12.5} & \multirow[b]{2}{*}{15} & \multirow[b]{2}{*}{1050} \\
\hline & 300 & & & & & & & & & \\
\hline
\end{tabular}


Figure 4. Facade section in the on-site test. Detail of double wall in red. (Source: compiled by author).

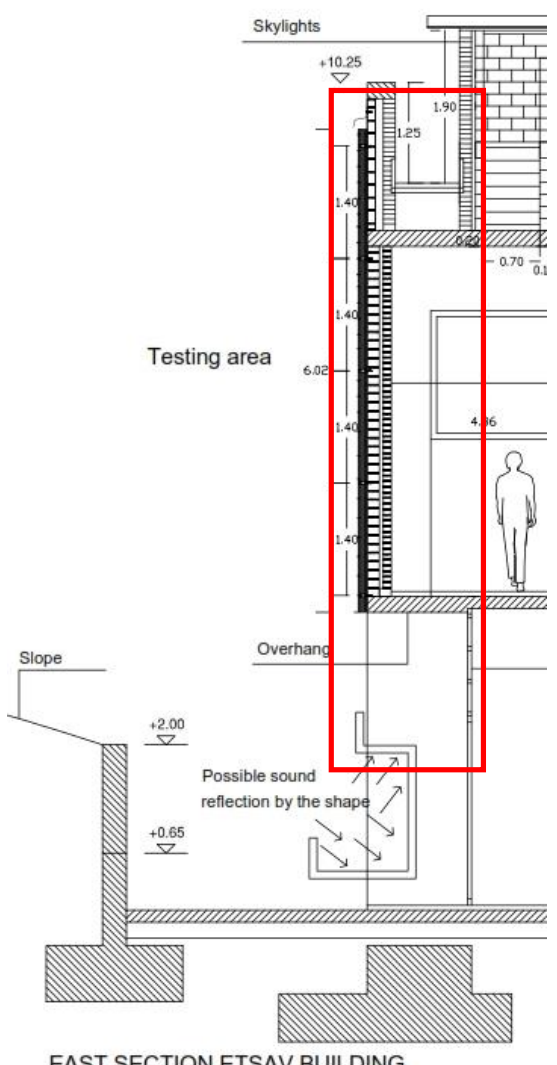

EAST SECTION ETSAV BUILDING
Figure $\mathbf{5}$. Zoom of vertical section testing area LVF assembly installed, where $\mathbf{A}$ is the LVF assembly system, $\mathbf{B}$ is the lightweight system and $\mathbf{C}$ is a double sheet, with the base wall of the ETSAV building. (Source: adapted by authors).

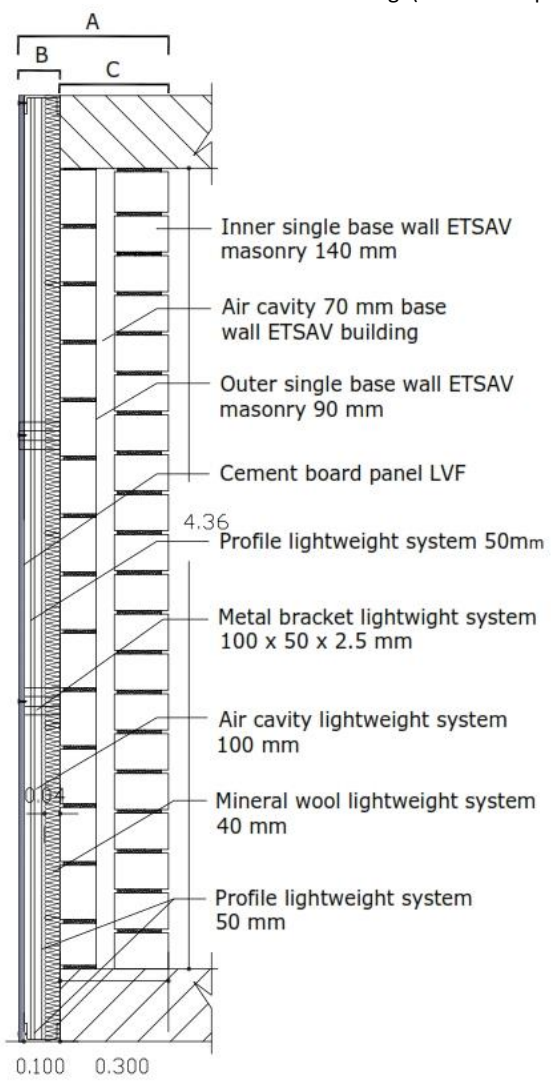

Figure 6. Photographs of the three configurations of the outer sheet of the LVF assembly applied on-site in test 1 (Source: compiled by authors)

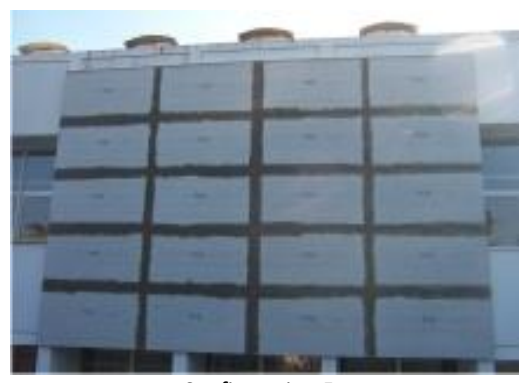

Configuration Fa

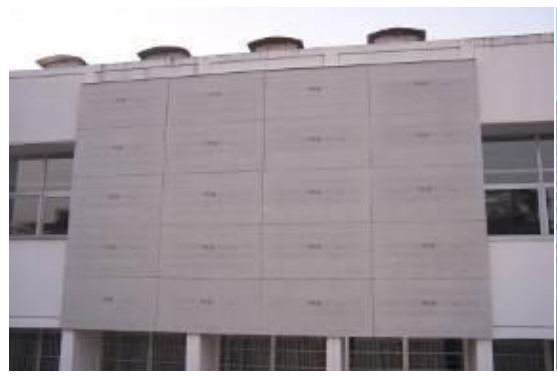

Configuration $\mathrm{Fb}$

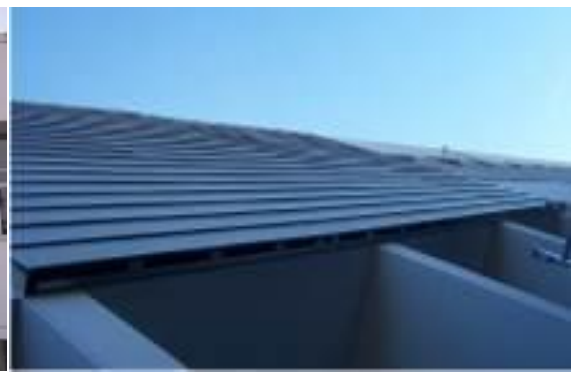

Configuration Fd

Figure 7. Diagram of the opening degree adjustment for ventilation. The intermediate air chamber ventilates through the upper and lower edges of the tested LVF façade section. The opening levels of the surface used to ventilate the intermediate air chamber are: $1=0 \%$ opening surface, $2=25 \%$ opening surface, $3=50 \%$ opening surface, $4=75 \%$ opening surface, $5=100 \%$ opening surface. $A$ is the assembly of the LVF system, B is the lightweight system and C is the base wall. (Source: compiled by authors).

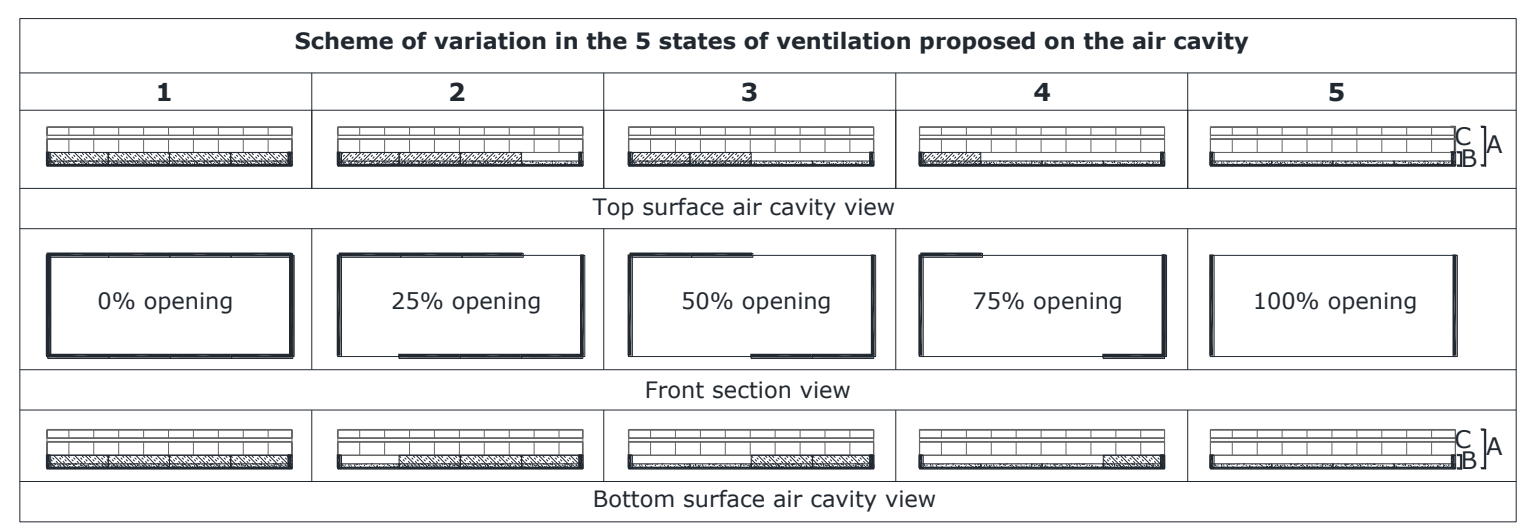


The following Figures 8, 9 and 10 indicate the results in the difference of standard levels $D_{2 m, n T}$ obtained in the three configurations of the outer sheet of the LVF prototype ( $\mathrm{Fa}, \mathrm{Fb}$ and $\mathrm{Fd}$ ) with 5 progressive degrees of opening of the intermediate air chamber (0, 25, 50, 75, 100\%). Fa 5 (100\% open) and Fd 1 ( $0 \%$ open) measures were not included because the results obtained were wrong, due to the problem with experimental devices.

Figure 8. Configuration Fa: results obtained in the difference of standard levels $D_{2 m, n T}$, with the five proposed opening levels. The red circle indicates the position of coincidence frequency $\left(f_{c}\right)(2500 \mathrm{~Hz})$ of the outer sheet.

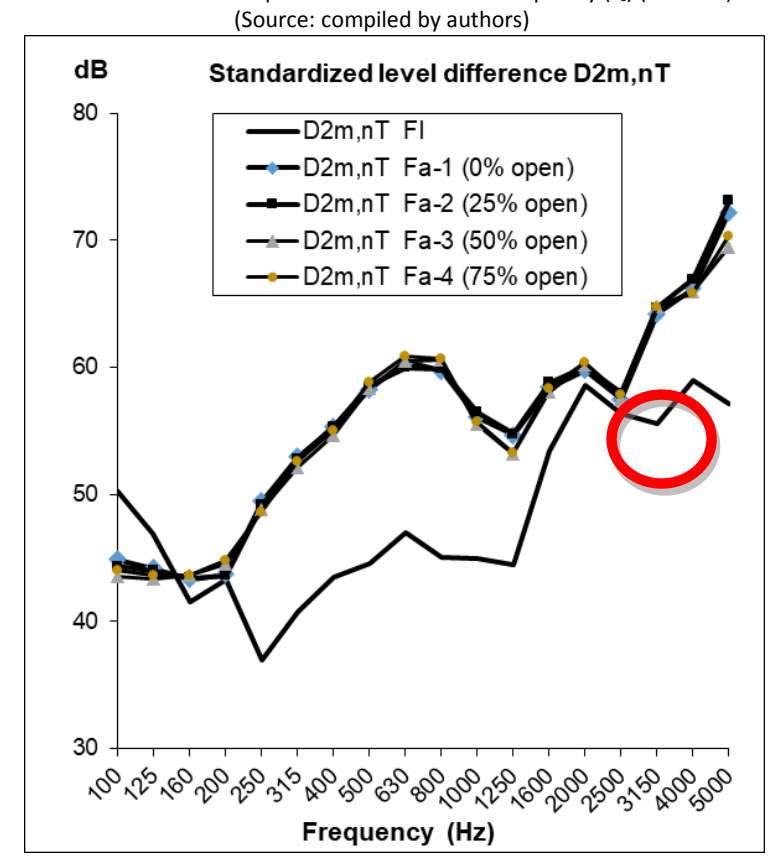

Figure 9. Configuration Fb: Results obtained in the difference of standard levels $D_{2 m, n T}$, with the five proposed opening levels. The red circle indicates the position of the coincidence frequency $\left(f_{c}\right)(2500 \mathrm{~Hz})$ of the outer sheet.

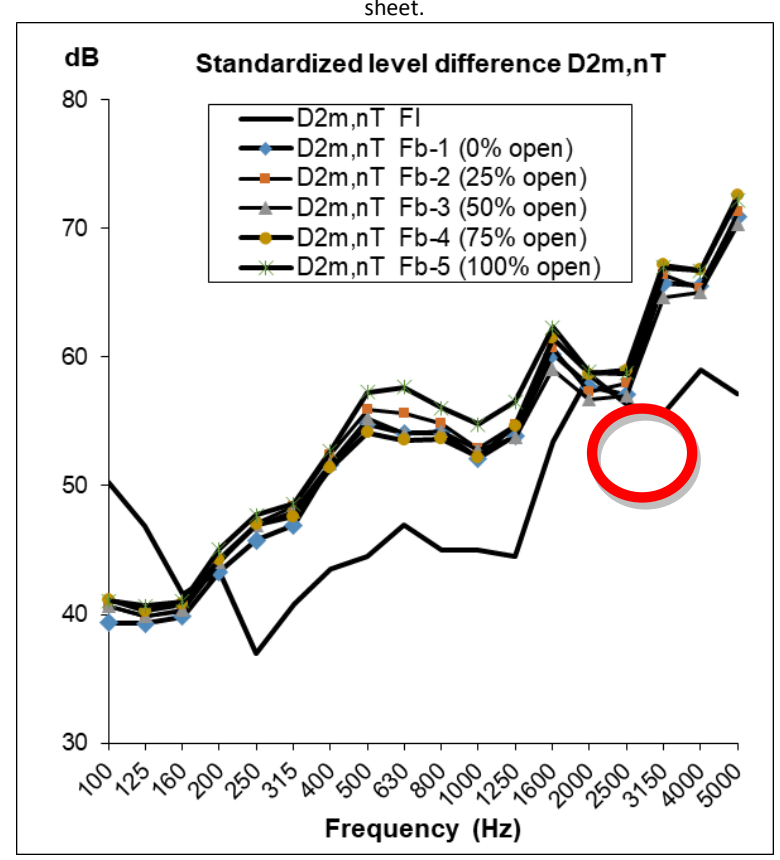


Figure 10. Configuration Fd: Results obtained in the difference of standard levels $D_{2 m, n t}$, with the five proposed opening levels. The red circle indicates the position of coincidence frequency $\left(f_{c}\right)(2500 \mathrm{~Hz})$ of the outer sheet. (Source compiled by authors)

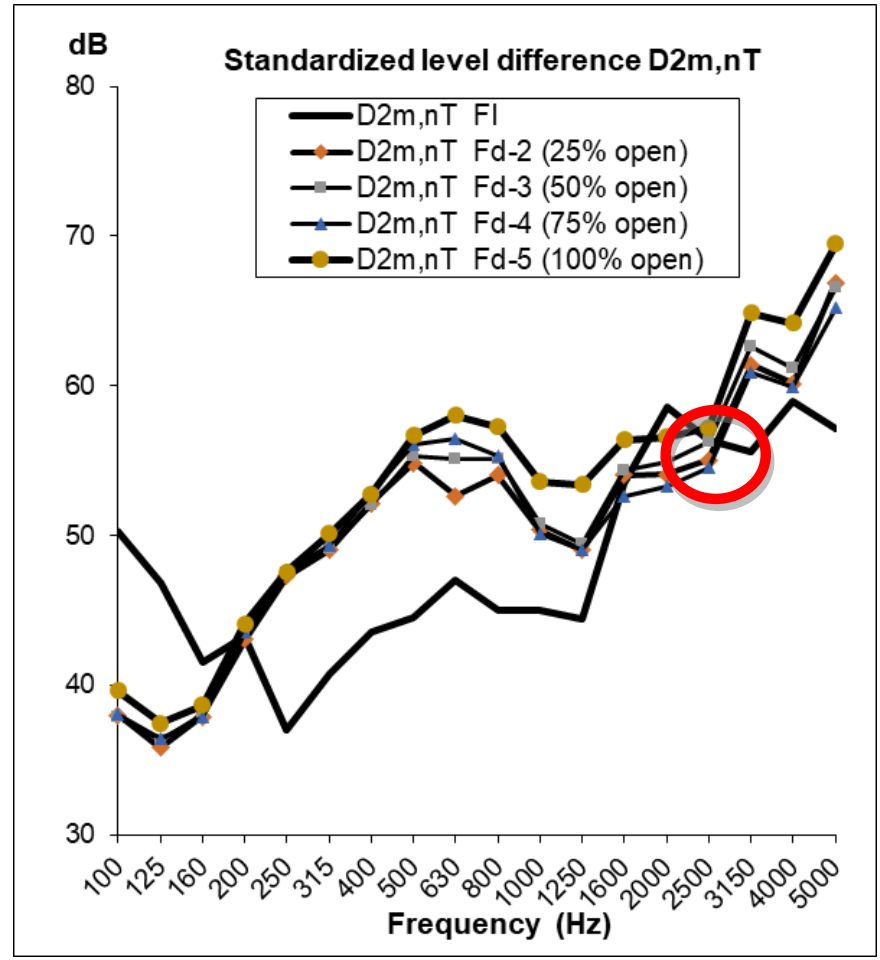

Table 4. Results of the parameter $\mathrm{D}_{2 m, \mathrm{nTw}}(\mathrm{C} ; \mathrm{Ctr}$ ) obtained with the five proposed opening levels. $\left({ }^{*}\right)$ These results were not obtained correctly. (Source: compiled by authors).

\begin{tabular}{|c|c|c|c|c|c|c|}
\hline & \multicolumn{5}{|c|}{ Standardised façade sound level $D_{2 m, n T w}(C ; C t r)$ on site test } & \multirow[b]{3}{*}{$\begin{array}{l}\text { Base Wall } \\
\text { (FI) } 30 \mathrm{~cm}\end{array}$} \\
\hline & 1 & 2 & 3 & 4 & 5 & \\
\hline $\begin{array}{c}\text { LVF } \\
\text { Air cavity } 100 \\
\mathrm{~mm}\end{array}$ & $\begin{array}{c}\text { Opening } \\
\text { air cavity } \\
0 \%\end{array}$ & $\begin{array}{l}\text { Opening } \\
\text { air } \\
\text { cavity } \\
25 \%\end{array}$ & $\begin{array}{l}\text { Opening } \\
\text { air } \\
\text { cavity } \\
50 \%\end{array}$ & $\begin{array}{l}\text { Opening } \\
\text { air } \\
\text { cavity } \\
75 \%\end{array}$ & $\begin{array}{c}\text { Opening } \\
\text { air cavity } \\
100 \%\end{array}$ & \\
\hline $\mathrm{Fa}$ & $\begin{array}{c}58 d B \\
(-2 ;-5)\end{array}$ & $\begin{array}{c}59 d B \\
(-2 ;-6)\end{array}$ & $\begin{array}{c}58 d B \\
(-3 ;-5)\end{array}$ & $\begin{array}{c}59 d B \\
(-3 ;-6)\end{array}$ & $(*)$ & $47 \mathrm{~dB}(0 ;-2)$ \\
\hline $\mathrm{Fb}$ & $\begin{array}{l}55 \mathrm{~dB} \\
(-2 ;-5)\end{array}$ & $\begin{array}{c}56 \mathrm{~dB} \\
(-2 ;-5)\end{array}$ & $\begin{array}{c}55 \mathrm{~dB} \\
(-2 ;-5)\end{array}$ & $\begin{array}{l}54 \mathrm{~dB} \\
(0 ;-3)\end{array}$ & $\begin{array}{c}57 d B \\
(-2 ;-5)\end{array}$ & \\
\hline $\mathrm{Fd}$ & $(*)$ & $\begin{array}{l}55 \mathrm{~dB} \\
(-4 ;-6)\end{array}$ & $\begin{array}{l}55 \mathrm{~dB} \\
(-4 ;-6)\end{array}$ & $\begin{array}{c}56 \mathrm{~dB} \\
(-5 ;-7)\end{array}$ & $\begin{array}{l}57 d B \\
(-3 ;-6)\end{array}$ & \\
\hline
\end{tabular}

In the above set of graphs (Figures 8, 9 and 10), more favourable acoustic insulation can be observed in the LVF assembly with regards to the base wall (FI) (continuous black line), in any of the 3 LVF configurations tested in on-site test 1 , particularly in the range of medium and high frequencies, with significant recovery after the critical frequency value $\left(f_{c}\right), 2500 \mathrm{~Hz}$ of the Cement Board of the lightweight outer sheet. At low frequencies of $<200 \mathrm{~Hz}$, the LVF shows less insulation owing to the incidence of the critical frequency $\left(f_{c}\right) 139 \mathrm{~Hz}$ of wall 1 of the inside sheet (Table 1).

There was no significant difference between the fully closed chamber (0\%) and the fully open chamber (100\%) in any of the assembly configurations of the lightweight outer sheet. There was only a slight variation in the Fd configuration (continuous outer slatted sheet) (the measurements Fd-1, 0\% open, and Fa-5, 100\% open, were taken as erroneous and are not valid: see the orange line). At spectral level, the Fa continuous outer sheet assembly always shows higher acoustic insulation levels than other configurations, even at low frequencies (Table 4). 
- Among other technical and architectural advantages, the use of LVF as a façade increases the level of acoustic insulation of a heavy based wall $\left(>150 \mathrm{~kg} / \mathrm{m}^{2}\right)$, with improved overall values of the initial acoustic reduction index $(\triangle R)$ of between $5 \mathrm{~dB}$ and $7 \mathrm{~dB}$ compared to a single wall, depending on the characteristics of the initial base wall. In the values of the acoustic reduction index $R$ by frequency bands, up to a maximum of $\Delta R=20 \mathrm{~dB}$ is observed in the range of medium-high frequencies, which are also more noticeable in airborne noise transmission. The implementation of a surface of openings for its ventilation, placed in the same front of LVF does not necessarily represent a significant decrease in acoustic performance of the façade assembly, compared to the location of a non-ventilated intermediate air chamber.

- Regarding the influence in the level of acoustic insulation of the LVF assembly, when the degree of opening of the ventilation surface of the intermediate air chamber is modified, the results showed that this variation does not generally represent a significant reduction in improving the level of acoustic insulation in relation to a nonventilated intermediate air chamber.

- From the results obtained in this on-site test, the authors considered the development of another test in a more controlled environment such as the laboratory, to specifically analyse the configuration Fa (outer lightweight continuous sheet with joints sealed between panels), for which the best results were obtained.

\section{Acknowledgements}

This research has been possible thanks to the people and businesses that provided support by performing various measuring and simulation tests: the Department de Tecnologia de l'Arquitectura of the Universitat Politècnica de Catalunya (UPC); Joanna Cárdenas, Javier Blas, Jordi Parra, Jordi Ràfols \& Dasil Fernández, of Knauf GmbH Spain; Jordi Romeu of the Laboratori d'Enginyeria Acústica i Mecànica (LEAM)(UPC); Escuela Técnica Superior de Arquitectura del Vallés (ETSAV) of the UPC.

Adjemia, A. (2011). La evolución de las fachadas ventiladas, nuevos materiales y sistemas constructivos. Valencia: Universidad Politécnica de Valencia.

Arau, H. (1999). ABC de la acústica arquitectónica. Barcelona: CEAC, DL.

Blasco, M., Crispin, C., \& Ingelaere, B. (2004). Acoustical performances of Double Ventilated Glass facades. Inter.noise 2004 The 33 rd International Congress and Exposition on Noise Control Engineering, pp. 161-170. Prague: Institute of Noise Control Engineering.

Braganca, L., Wetzel, C., Buhagiar, V., \& Verhoef, L. (2007). COST C16 Improving the Quality of Existing Urban Building Envelopes IV. Delft: Delft University Press.

Dijckmans, A., Vermeir, G., \& Lauriks, W. (2010). Sound transmission through finite lightweight multilayered structures with thin air layers. Acoustical Society of America, 128(6), pp.3513-3524.

Fahy, F. (1985). Sound and structural vibration. Academic Press.

Frutos, B., Olaya, M., \& Zaballos, J. (2008). Acoustic Analysis of Constructive Solutions with Sheets Interconnected with a Metallic Self Supporting Frame. 2nd Conference on Construction Research, pp. 905-919. Madrid: Consejo Superior de Investigaciones Científicas (España).

Halliwell, R., Nightingale, T., Warnock, A., \& Birta, J. (1998). Gypsum Board Walls: Transmission Loss Data. Internal Report IRC-IR-761. Institute for Research in Construction. National Research Council of Canada.

Harris, C. (1995). Handbook of acoustical measurements and noise control. New York: McGraw Hill.

Hongisto, V. (2000). Airborne sound insulation of wall structures-measurement and prediction methods. Helsinki: Laboratory of Acoustics and Audio Signal Processing Helsinki University of Technology.

Hopkins, C. (2007). Sound Insulation. Oxfort: Elsevier.

Knauf Company. (march of 2009). Aquapanel Outdoor. Hoja técnica w38, Edición 02/05. España.

Ministerio de Fomento, Gobierno de España. (2008). Technical Building Code CTE, DB-HS1, Spain. http://www.codigotecnico.org/index.php/menusalubridad

Mosqueira, A. (2003). Revestimiento de fachadas en madera. Revista CIS-Madera, 11, pp.6-16. 
Niampira Daza, A. (2014). Table 1.1. Summary of regulation in the use of double wall chambers, page 26. Barcelona: Universitat Politècnica de Catalunya.

Paricio, I., \& Pardal, C. (2006). La fachada ventilada y ligera. Barcelona : Bisagra.

Pérez, J., Álvarez, A., \& Montero, E. (2007). Fachadas ventiladas y aplacados. Requisitos constructivos y estanqueidad: Manual Básico. Murcia: Consejería de Obras Públicas, vivienda y Transportes.

Ruiz, L., Delgado, E., Neila, F., \& Vega, S. (2012). Comparativa del comportamiento Acústico entre Fachadas Multicapas Ligeras y Fachadas Tradicionales. Materiales de Construcción, 307, pp. 397-409.

UNE EN ISO 717-1. (1997). Acoustics. Rating of sound insulation in buildings and of building elements - Part 1: Airborne sound insulation.

UNE-EN ISO 140-5. (1998). Measurement of acoustic insulation in buildings and construction elements. Part 5: On-site measurements of the airborne acoustic insulation of façade elements.

UNE-EN ISO 12354-3. (2001). Acoustics in building. Estimate of the acoustic characteristics of buildings based on the characteristics of their elements. Part 3: Airborne acoustic insulation against outside noise.

UNE-EN ISO 140-5. (1999). Acoustics. Measurement of acoustic insulation in buildings and their construction elements. Part 5: On-site measurements of the airborne acoustic insulation of façade elements and façades.

Warnock, \& Quirt. (1997). Control of sound transmission through gypsum board walls. Institute of Research in Construction (IRC), National Research Council of Canada. 